\title{
Strength development characteristics of concrete produced with blended cement using ground granulated blast furnace slag (GGBS) under various curing conditions
}

\author{
SHAHAB SAMAD ${ }^{1,2, *_{0}}$, ATTAULLAH SHAH ${ }^{2}$ and MUKESH C LIMBACHIYA ${ }^{1}$ \\ ${ }^{1}$ School of Civil Engineering and Construction, Kingston University, London, UK \\ ${ }^{2}$ Department of Civil Engineering, City University of Science and Information Technology, Peshawar, Pakistan \\ e-mail: shahabsamad54@hotmail.com; drshah965@gmail.com; M.Limbachiya@kingston.ac.uk
}

MS received 31 May 2016; revised 2 October 2016; accepted 1 January 2017

\begin{abstract}
To reduce the embodied carbon dioxide of structural concrete, Portland cement (PC) in concrete can be partially replaced with ground granulated blast furnace slag (GGBS). In this research effect of partial replacement of cement with GGBS on strength development of concrete and cured under summer and winter curing environments is established. Three levels of cement substitution i.e., 30\%, $40 \%$ and $50 \%$ have been selected. Early-age strength of GGBS concrete is lower than the normal PC concrete which limits its use in the fast-track construction and post-tensioned beams which are subjected to high early loads. The strength gain under winter curing condition was observed as slower. By keeping the water cement ratio low as 0.35, concrete containing GGBS up to $50 \%$ can achieve high early-age strength. GGBS concrete gains more strength than the PC concrete after the age of 28 day till 56 day. The mechanical properties of blended concrete for various levels of cement replacement have been observed as higher than control concrete mix having no GGBS.
\end{abstract}

Keywords. Embodied; slag; partial replacement; compressive strength; curing; modulus of elasticity; flexural strength.

\section{Introduction}

"Sustainable development" was defined by Brundtland Commission [1] as "the development that meets the needs of the present without compromising the ability of future generations to meet their own needs". The extensive emission of green house gases (GHG) due to industrialisation and use of fossil fuels in automobiles has led to global warming, climate changes and other environmental degradations, which has further intensified the need for sustainable development [2]. Embodied $\mathrm{CO}_{2}\left(\mathrm{ECO}_{2}\right)$ is the measure of the amount of $\mathrm{CO}_{2}$ emissions generated from the energy needed for the raw material extraction, processing, transportation, assembling, installation, disassembly and deconstruction for any system over the duration of a product's life. The $\mathrm{ECO}_{2}$ of the construction material is one of the highest, such as for cement it is $913 \mathrm{~kg} /$ tonne [3]. There is a general understanding that one tonne of cement production leads to almost one tonne of $\mathrm{CO}_{2}$ emission. On the other hand, concrete as construction material has been one of the major inputs for socio-economic development of societies. It is the second largest used material after water and it stands at 2 tonnes per capita per year. Hence, the

*For correspondence global production of concrete would continue to increase with time [4].

The supplementary cementitious material (SCM) has been extensively used in the development of high-performance concrete (HPC), which include fly ash, silica fumes, rice husk ashes and ground granulated blast furnace slag (GGBS). Apart from improvement of the properties of concrete in fresh and hardened form, the use of SCM has also reduced the consumption of cement in concrete, thereby reducing the emissions of $\mathrm{CO}_{2}$ in the atmosphere during manufacturing of cement. The extensive emissions of GHGs such as $\mathrm{CO}_{2}$, SOx and NOx have led to many environmental issues like global warming, climate change and desertification, etc. There is growing pressure over the construction industry and concrete technologists to reduce the consumption of cement by incorporating SCM and chemical admixtures in concrete. Such kind of concrete are also regarded as "sustainable concrete" [5].

GGBS is a by-product obtained during the manufacture of iron in the blast furnace. It is economically available in large quantities, requiring storage facilities and, therefore, it is suitable for use in ready-mix concrete, in the production of large quantities of site-batched concrete and in precast product manufacturing. Blast furnaces are fed carefully with controlled mixtures of iron ore, coke and limestone at 
a temperature of $\sim 2000^{\circ} \mathrm{C}$. The iron ore is reduced to iron and sinks to the bottom of the furnace. The remaining material that floats on top is the slag. The annual production of GGBS in China alone is $\sim 15$ million tonnes, which is used as raw material in cement production, concrete and pavements [15]. In ref. [6], the authors reported that replacement of cement by slag up to $40 \%$ has greater compressive and flexural strength than normal concrete. In ref. [7], the authors studied the behaviour of GGBS-added concrete at elevated temperatures. The cementitious properties of GGBS depends on the chemical composition of the GGBS slag, alkali concentration of the reacting system, glass content of the GGBS, fineness of the GGBS and Portland cement and temperature during the early phases of the hydration process [8].

GGBS has been used as partial replacement to cement in many researches in various forms to develop high-strength and high-performance concrete. Alkali silicate activated slag cement at higher temperatures was also used by studies in refs. [9-12]. In ref. [13], the author worked on the use of pelletised blast furnace slag and its effects on the freezeand-thaw durability characteristics and reported its good performance in concrete. Although partial replacement of cement by SCM reduced the cement consumption, it entailed some inherit problems associated with their uses. The researchers have developed novel techniques to overcome such shortcomings in the use of SCM $[14,15]$. The strength development of concrete having SCM-like slag is relatively slower than normal concrete and usually the optimum compressive strength is achieved at later ages than 28 days and it is recommended to measure the strength of such concrete at 56 days [16]. The use of GGBS has reduced the detrimental effects of silicates in aggregates and the expansion in concrete has been reduced as a result [17]. The Missouri Department of Transportation USA and University of Missouri worked on a joint project on the optimization of cement replacement by slag and identified the range of $40-60 \%$ for highest strength development of concrete [18].

The physical properties of GGBS vary significantly from source to source and region to region as there is no standardised manufacturing process. Hence, its effects on the properties of concrete in fresh and hardened form also change significantly. The curing process also affects the properties of concrete made from ordinary or blended cement incorporating GGBS. Water curing was found more effective than heat curing $[19,20]$. Slow steam curing of slag-added concrete has gained strength more than waterand air-cured specimen [13].

Concrete made with slag cement has higher long-term compressive and flexure strengths compared to PC concrete and it varies for different curing conditions, mix proportions and age of testing. When PC reacts with water, it forms calcium silicate hydrate (CSH) and calcium hydroxide $\mathrm{Ca}(\mathrm{OH})_{2}$. $\mathrm{CSH}$ is a glue that provides strength to the concrete and holds it, while $\mathrm{Ca}(\mathrm{OH})_{2}$ is a by-product and does not contribute to the strength of concrete. When slag is used as part of the cementitious constituent in concrete, it reacts with water and $\mathrm{Ca}(\mathrm{OH})_{2}$ to form more CSH gel and increases the strength [21].

Compressive strength of concrete mixtures containing GGBS is increased as the level of GGBS is increased but after an optimum point, which is $\sim 55 \%$ of the total binder content, further addition of GGBS did not improve the compressive strength of concrete. The strength gain is slow in concrete containing GGBS because the pozzolanic reaction is slow and depends on the calcium hydroxide availability [22].

From a structural point of view, GGBS replacement reduces heat of hydration, enhances durability, including higher resistance to sulphate and chloride attack, when compared with normal concrete. On the other hand, it also contributes to environmental protection because it minimises the use of cement during the production of concrete [23]. Form striking time is not increased if the replacement of GGBS in concrete is limited to 50\%. [24].

In this research, the effects of the partial replacement of cement with GGBS on the engineering properties of concrete under different curing conditions have been studied. The use of GGBS in concrete tends to slow down the earlyage strength, which limits its use in the fast-track construction and post-tensioned concrete which are subjected to high early loads. Early-age strength of concrete containing GGBS can be increased by reducing the water/cement ratio.

\section{Research significance}

The non-uniform physical properties of slag found in various parts of the world and limited research data on the performance of concrete produced with cement having GBBS has been the major motivation for this research. It is expected that the results of the research will add to the existing data on use of blended cement in concrete and its performance under various curing conditions. The early-age strength of blended concrete is relatively less than the normal concrete, which restricts its use in many important projects. Based on various trial mixing, the optimal level of water cement ratio, chemical admixtures and replacement of cement by slag has been established under various curing conditions. This will help in further research in standardising the properties and mixing of the concrete made with blended cements.

\section{Environmental benefits of GGBS concrete}

The environmental profile for the production of 1 tonne of GGBS, compared with typical values of PC, is presented in table 1 by Higgins [25]. For the production of GGBS, the impact for processing the granulated slag to produce GGBS 
Table 1. Environmental burden for the manufacture of GGBS after [25].

\begin{tabular}{|c|c|c|c|}
\hline \multirow{2}{*}{ Source } & \multirow{2}{*}{ Measured as } & \multicolumn{2}{|c|}{ Impact } \\
\hline & & Manufacture of 1 tonne of GGBS & Manufacture of 1 tonne of PC \\
\hline Climate change & $\mathrm{CO}_{2}$ equivalent & 0.05 tonne & 0.95 tonne \\
\hline Energy use & Primary energy & $1300 \mathrm{MJ}$ & $5000 \mathrm{MJ}$ \\
\hline Mineral extraction & Weight quarried & 0 & 1.5 tonnes \\
\hline Waste disposal & Weight to tip & 1 tonne saved & 0.02 tonnes \\
\hline
\end{tabular}

Table 2. Calculated environmental impacts for 1 tonne of concrete after Higgins [25].

\begin{tabular}{lccr}
\hline Impact & $100 \%$ PC & $50 \%$ GGBS & $30 \%$ PFA \\
\hline Greenhouse gas $\left(\mathrm{CO}_{2}\right)$ & $142 \mathrm{~kg}(100 \%)$ & $85.4 \mathrm{~kg}(60 \%)$ & $118 \mathrm{~kg}(83 \%)$ \\
Primary energy use & $1070 \mathrm{MJ}(100 \%)$ & $760 \mathrm{MJ}(71 \%)$ & $925 \mathrm{MJ}(86 \%)$ \\
Mineral extraction & $1048 \mathrm{~kg}(100 \%)$ & $965 \mathrm{~kg}(92 \%)$ & $1007 \mathrm{~kg}(96 \%)$ \\
\hline
\end{tabular}

has been considered and no impact has been taken into account for the production of iron because slag is produced as a by-product in the production of iron, and if not utilised, will go to land fill. The replacement level and the need for extra cementitious content are the important factors in selecting the most sustainable material for concrete production. GGBS is highly cementitious and can usually replace Portland cement by $50 \%$ or more.

The environmental impacts benefits of using GGBS and PFA in concrete studied by the UK Concrete Industry Alliance project were tabulated by Higgins [25] and are given in table 2 . The environmental impacts are per tonne production of a C30 concrete. As shown in table 2, replacement of $50 \%$ Portland cement with GGBS saves $40 \% \mathrm{CO}_{2}$ emissions in concrete. It has a negligible effect on mineral extraction, which is $8 \%$. GGBS and PFA are widely available in the UK and transportation distance between the point of production and the point of use is comparable with those of Portland cement. Higgins [25] concluded that in 2005 the use of GGBS and PFA saved the UK 2.5 million tonnes of carbon dioxide emissions, 2 million megawatt hours of energy, 4 million tonnes of mineral extraction and 2.5 million tonnes of material sent to landfill. The $\mathrm{CO}_{2}$ emissions are compared in figure 1.

The data published by the Building Material Research Centre of the Aachen University of Technology in Germany using industrial by-products in cement can result in significant savings in energy and reductions in $\mathrm{CO}_{2}$ emissions. By using $60 \%$ blast furnace slag in blended cement, reductions in energy consumption of $\sim 43 \%$ and that in $\mathrm{CO}_{2}$ emissions of $\sim 50 \%$ in the production of $1 \mathrm{~m}^{3}$ of concrete of strength class C25/30 can be achieved (considering the transportation of the aggregate over a distance of $40 \mathrm{~km}$ and cement over $80 \mathrm{~km}$ ) [26].

In Milharbour, London, over $800 \mathrm{~m}^{3}$ of concrete with $70 \%$ GGBS was poured in the raft foundation of Milharbour in London Docklands. Milharbour is Europe's tallest residential development with over 700 apartments located in two interlinking towers rising up to 50 storeys. The concrete Industry Alliance within a DETR-supported project (1999) calculated the environmental impact of GGBS and found 50\% reductions in GHGs for the Milharbour project by using $70 \%$ GGBS [27].

In the extension of West Thames College, 35\% GGBS was used in the flat slab structure. As PC production is responsible for $6 \%$ of the global carbon emissions, its partial replacement with GGBS was environmentally beneficial as less cement was quarried and resulted in less waste product of the steel industry to be land filled. The delivery cost of the blended cement concrete was 2-3\% cheaper than the standard concrete mix. Architecturally, the light colour of GGBS concrete provided a nice finish to the fair-faced walls, columns and slabs. Formwork striking times were extended to account for slower strength gain. Vertical forms were delayed from 1 to 2 days and slabs cast in subsequent weeks were delayed to at least 11 days rather than a week for PC concrete. Overall these were acceptable prices to pay for the financial saving and environmental benefit [28].

The Shard is the tallest building in the European Union. It is $310 \mathrm{~m}$ high and has 95 floors, including plant floors with 72 habitable floors. The Shard is an unusual mixture of concrete and steel, and has a concrete basement. Here, $75 \%$ GGBS was used in the base slab. GGBS was used not only to reduce the propensity for early-age cracking but also to reduce embodied $\mathrm{CO}_{2}$. An innovative approach was used on this project to allow construction above and below ground to start simultaneously. High replacement of cement with GGBS has the potential disadvantage of low early-age strength so the concrete was developed such that it could achieve sufficient strength gain to meet initial structural requirements within 14 days, with the full strength being achieved at 56 days. According to the Concrete Centre, the core had already reached 21 storeys high by the time that 


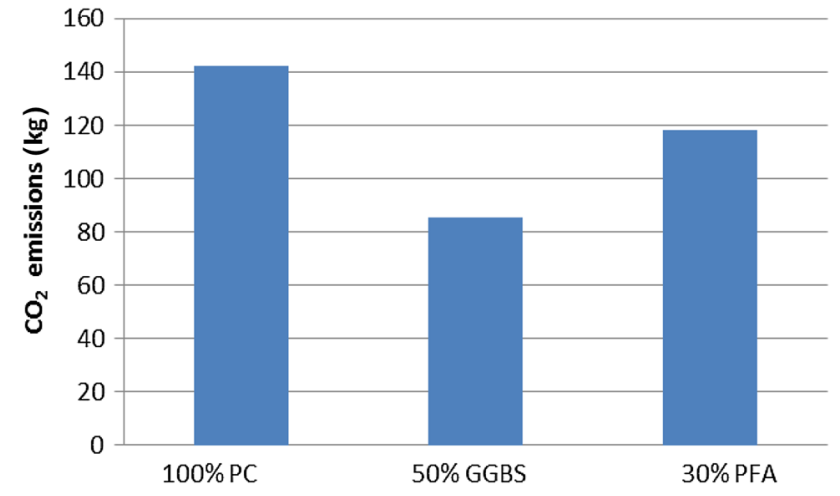

Figure 1. $\mathrm{CO}_{2}$ emissions after Higgins [25].

700 truckloads of concrete were poured into the basement to form the 3-m-deep raft foundation upon which the tower had to sit [29].

The production of $100 \mathrm{~m}^{3}$ concrete used 32 tonnes of cement. Replacing 50\% cement with GGBS saves 12.96 tonnes of $\mathrm{CO}_{2}$. A comparison of the $\mathrm{CO}_{2}$ emissions of Portland cement and Regen (GGBS) is given in figure 2 [30].

\section{Experimental program}

\subsection{Material}

4.1a Ground granulated blast furnace slag (GGBS): GGBS is a by-product obtained during the manufacture of iron in the blast furnace. GGBS is economically available in large quantities and suitable for production of large quantities of ready-mix concrete at site in precast product manufacturing. The granulated slag is dried and ground to a

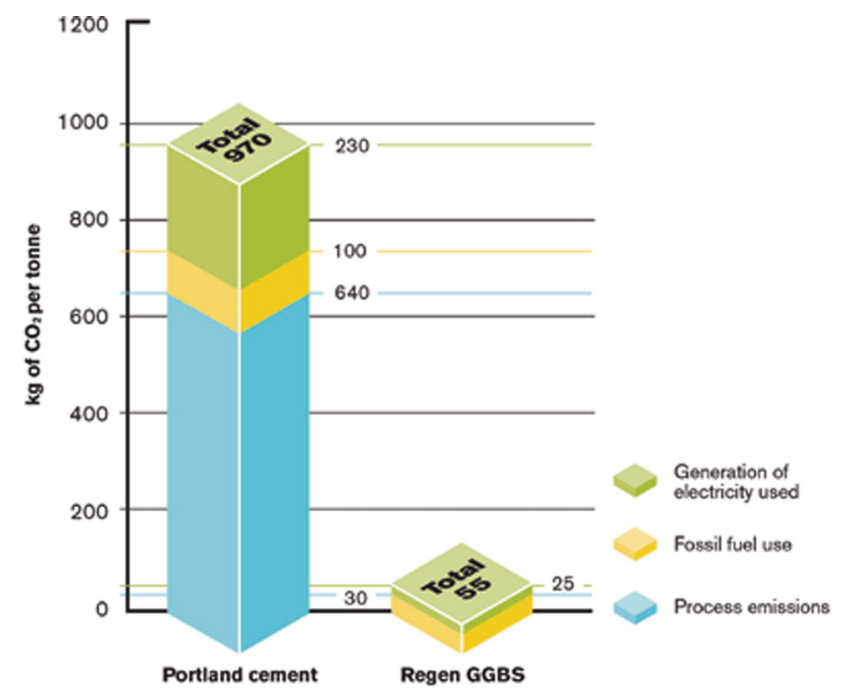

Figure 2. Typical $\mathrm{CO}_{2}$ emissions for Portland cement and GGBS [30].
Table 3. Typical constituents of GGBS after Hanson (2012).

\begin{tabular}{lc}
\hline Constituents & Percentage in GGBS \\
\hline Calcium oxide $(\mathrm{CaO})$ & 40 \\
Silica $\left(\mathrm{SiO}_{2}\right)$ & 35 \\
Alumina $\left(\mathrm{Al}_{2} \mathrm{O}_{3}\right)$ & 16 \\
Magnesia $(\mathrm{MgO})$ & 6 \\
Other- $\mathrm{Fe}_{2} \mathrm{O}_{3}$, etc. & 3 \\
\hline
\end{tabular}

fine powder which is called GGBS. It is off-white in colour and has a bulk density of $1200 \mathrm{~kg} / \mathrm{m}^{3}$. For a typical GGBS produced in the UK, the chemical constituents are given in table 3 .

4.1b Portland cement: Ordinary Portland cement (OPC) used conformed to BS EN 197-1 [31] and was classified as CEM-I. The Portland cement was stored in the laboratory to avoid exposure to humidity.

4.1c Superplasticiser (SP): High-performance liquid superplasticizers conforming to BS-EN 934-2 to achieve the required workability was used.

4.1d Aggregates: Graded natural sand with a maximum particle size of $5 \mathrm{~mm}$ and complying with the requirements of BS EN 12620-1 [32] was used as fine aggregate in the concrete mixes. Thames valley natural aggregates of lime stone were used as coarse aggregate in the concrete mixes. The maximum size of the aggregate used was $20 \mathrm{~mm}$.

\subsection{Concrete mix proportions}

Trial mixes of concrete were redesigned to achieve the 28 days' compressive strength of $60 \mathrm{MPa}$. In these concrete mixes, the overall maximum water/cement ratio was kept as 0.35 . To achieve a practical level of workability and cohesion that was suitable for pumping, concrete was designed for a target slump of $200 \mathrm{~mm}$. A superplasticiser was used to minimise water and cement contents to achieve low free w/c ratio. Mix proportions and details of the mixes are presented in table 4.

\subsection{Test samples}

Two batches of concrete were made for each concrete mix to cast samples. Sixty $100 \mathrm{~mm} \times 100 \mathrm{~mm}$ cubes were cast for each mix to measure the compressive strength development according to the British standard test method (BS EN 12390) [33] at the age of 1, 2, 3, 5, 7, 14, 28 and 56 days cured under different curing regimes.

\subsection{Curing environments}

Engineering performance of concrete cured under three different regimes was recorded. The following three 
Table 4. Concrete mix proportions.

\begin{tabular}{|c|c|c|c|c|c|c|c|c|}
\hline \multirow[b]{2}{*}{ Mix } & \multirow[b]{2}{*}{ Water (litres) } & \multicolumn{2}{|c|}{ Binder } & \multicolumn{2}{|c|}{ Aggregates } & \multirow[b]{2}{*}{$\mathrm{w} / \mathrm{c}$} & \multirow{2}{*}{$\begin{array}{l}\text { Super plasticiser } \\
(\mathrm{ml} / 100 \mathrm{~kg} \text { of } \mathrm{OPC})\end{array}$} & \multirow{2}{*}{$\begin{array}{l}\text { Density } \\
\left(\mathrm{kg} / \mathrm{m}^{3}\right)\end{array}$} \\
\hline & & OPC (kg) PFA & GGBS $(\mathrm{kg})$ & Coarse $(\mathrm{kg})$ & Fine $(\mathrm{kg})$ & & & \\
\hline $\begin{array}{l}\text { 70PC/30GGBS } \\
(30 \% \text { GGBS })\end{array}$ & 160 & 320 & 137 & 1285 & 500 & 0.35 & 1200 & 2400 \\
\hline $\begin{array}{l}\text { 60PC/40GGBS } \\
(40 \% \text { GGBS })\end{array}$ & 160 & 274 & 183 & 1285 & 500 & 0.35 & 1200 & 2400 \\
\hline $\begin{array}{l}\text { 50PC/50GGBS } \\
\quad(50 \% \text { GGBS })\end{array}$ & 160 & 229 & 228 & 1285 & 500 & 0.35 & 1200 & 2400 \\
\hline $\begin{array}{l}\text { 100PC-Control } \\
\text { (No GGBS) }\end{array}$ & 160 & 457 & - & 1285 & 500 & 0.35 & 1200 & 2400 \\
\hline
\end{tabular}

methods were chosen for curing the concrete, which have a close resemblance with the onsite curing environment in the UK.

4.4a Summer curing environment (C1): After casting concrete in the moulds, it was stored for $24 \mathrm{~h}$ at a laboratory temperature of $\sim 20 \pm 2^{\circ} \mathrm{C}$ and covered with plastic sheets to minimise the loss of moisture. After $24 \mathrm{~h}$, concrete was demoulded and sealed in air-tight plastic bags so that there was no loss of moisture and stored at a laboratory temperature of $20^{\circ} \mathrm{C}$. This curing environment has been titled as $\mathrm{C} 1$ and shown in figure 3 .

4.4b Winter curing environment (C2): After casting concrete, it was stored for $24 \mathrm{~h}$ within the moulds in the environmental chamber controlled at a temperature of $7^{\circ} \mathrm{C}$ and $55 \%$ relative humidity, which resembles the normal winter temperature in the UK. Moulds were covered with plastic sheets to minimise the loss of moisture. After $24 \mathrm{~h}$, concrete was demoulded and sealed in air-tight plastic bags to avoid any loss of moisture and stored in the environmental chamber controlled at $7^{\circ} \mathrm{C}$.

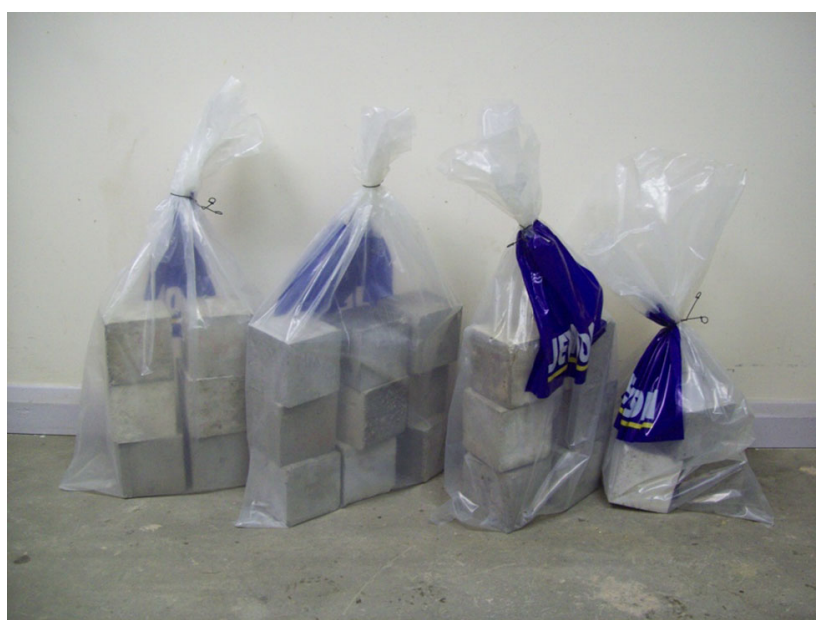

Figure 3. Test cubes under summer curing environment (C1).

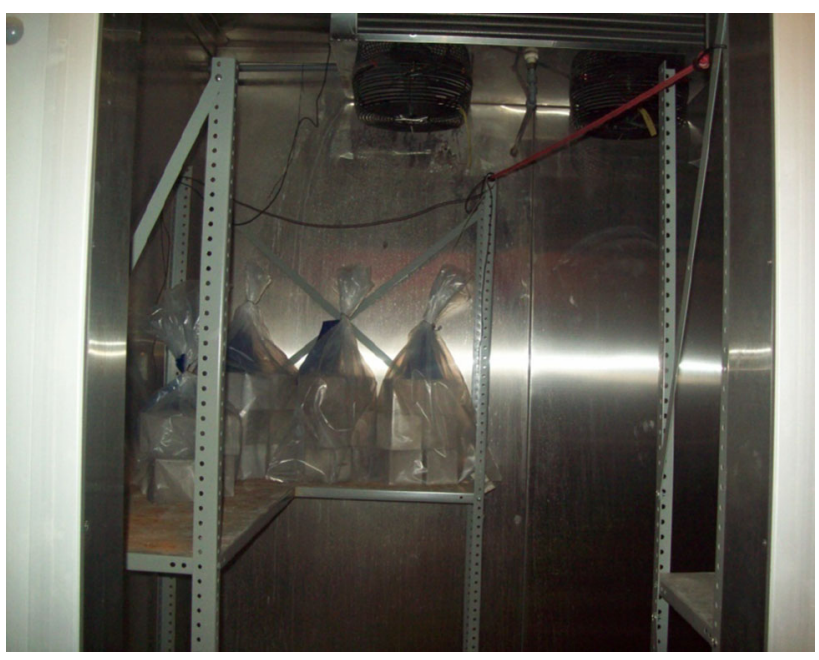

Figure 4. Test cubes under winter curing environment (C2).

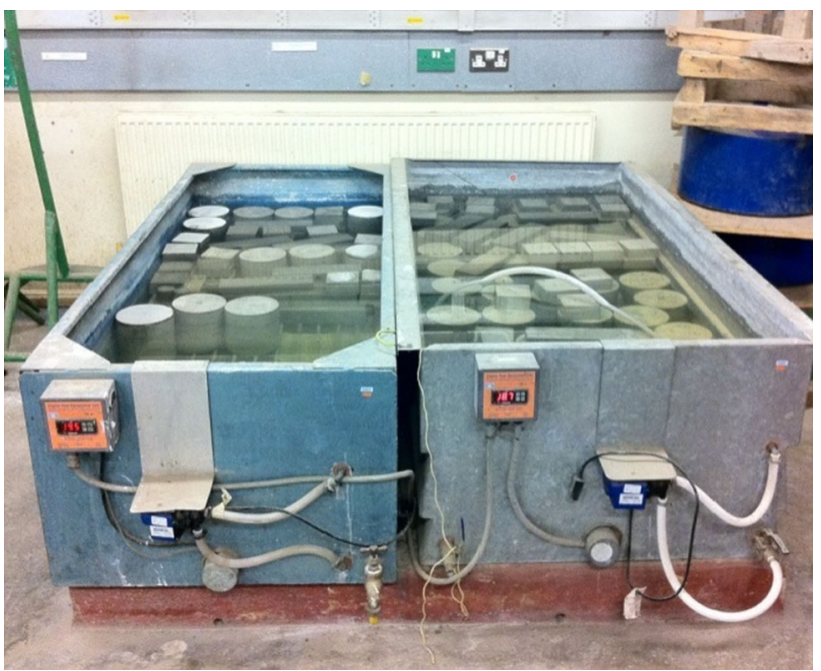

Figure 5. Concrete cubes under water curing environment (C3). 

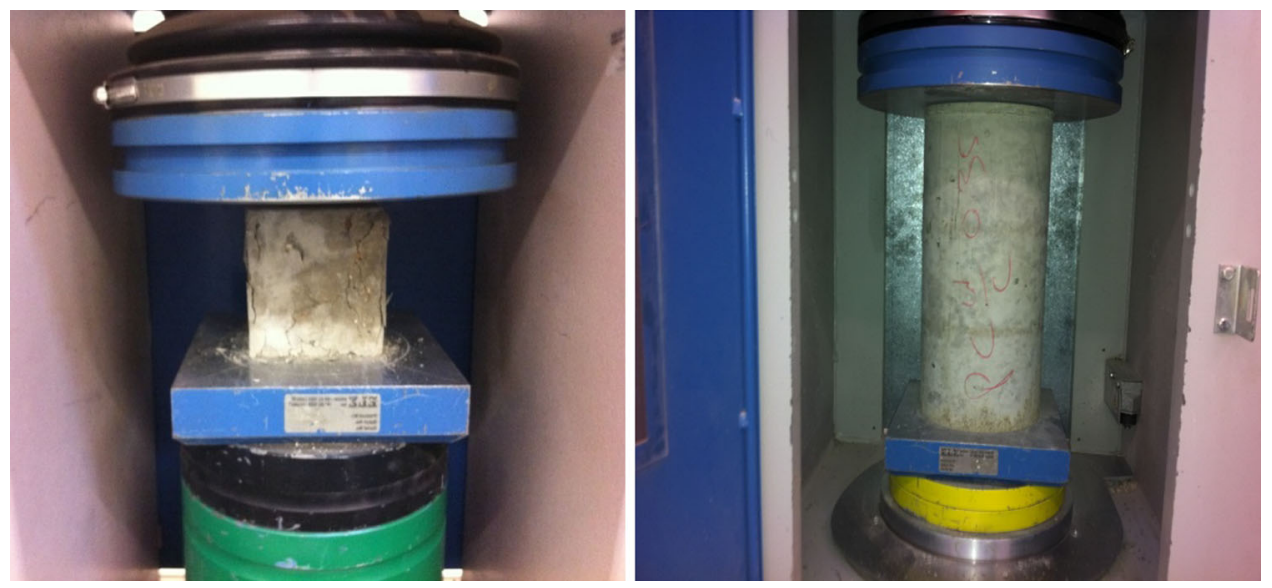

Figure 6. Compressive strength test using Avery Denison $2500 \mathrm{kN}$ machines.

Table 5. Compressive strength development of various concrete mixes for summer environment $\mathrm{C} 1$ and winter environment $\mathrm{C} 2$, expressed as $\%$ of 56 days' strength.

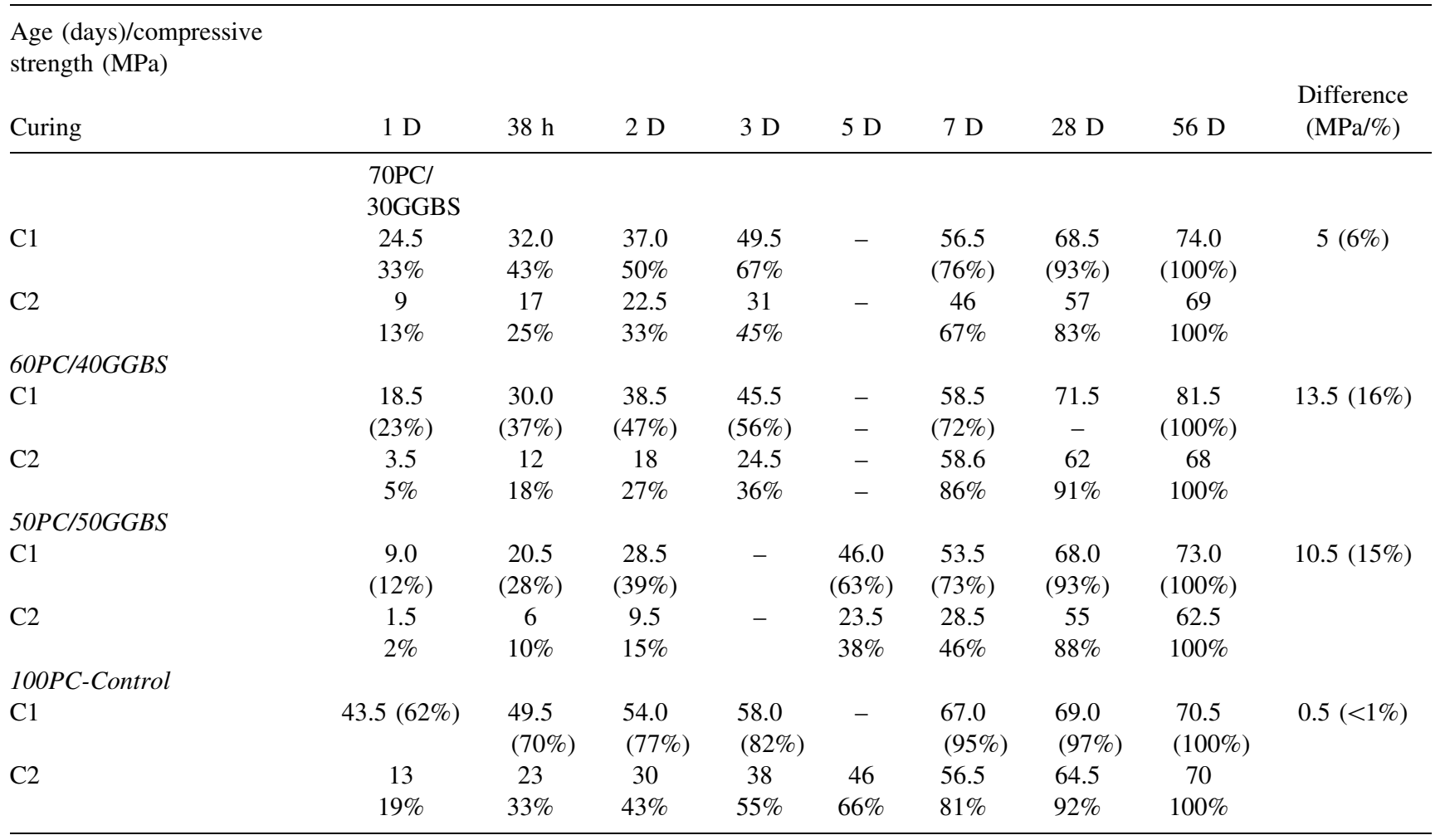

Concrete cubes cured under the $\mathrm{C} 2$ curing environment as shown in figure 4 .

4.4c Water curing environment (C3): After casting concrete in the moulds, it was stored at laboratory temperature of $20^{\circ} \mathrm{C}$ and was covered with plastic sheets. After $24 \mathrm{~h}$, the concrete was demoulded and immersed in a water chamber controlled at a temperature of $20 \pm 2^{\circ} \mathrm{C}$. Concrete stored under curing environment $\mathrm{C} 3$ is shown in figure 5 .

\section{Observations and analysis}

\subsection{Compressive strength development of GGBS concrete}

Two cube specimens from each mix and curing regime were tested for compressive strength using an Avery Denison $2500 \mathrm{kN}$ machine as shown in figure 6 . In the case of $>10 \%$ difference in two results, a third specimen was also tested. The concrete samples cured under regime C3 
Table 6. Compressive strength at the age of 28 and 56 days cured at $\mathrm{C} 3$.

\begin{tabular}{lcc}
\hline & \multicolumn{2}{c}{ Test age days/comp strength (MPa) } \\
\cline { 2 - 3 } Concrete mix & 28 days & 56 days \\
\hline 70PC/30GGBS & 72.0 & 75.0 \\
60PC/40GGBS & 72.0 & 82.0 \\
50PC/50GGBS & 68.0 & 74.5 \\
100PC-Control & 77.0 & 79.0 \\
\hline
\end{tabular}

(a) $\rightarrow 70 \mathrm{PC} / 30 \mathrm{GGBS} \longrightarrow-60 \mathrm{PC} / 40 \mathrm{GGBS} \longrightarrow 50 \mathrm{PC} / 50 \mathrm{GGBS} \longrightarrow-100 \mathrm{PC}$-Control

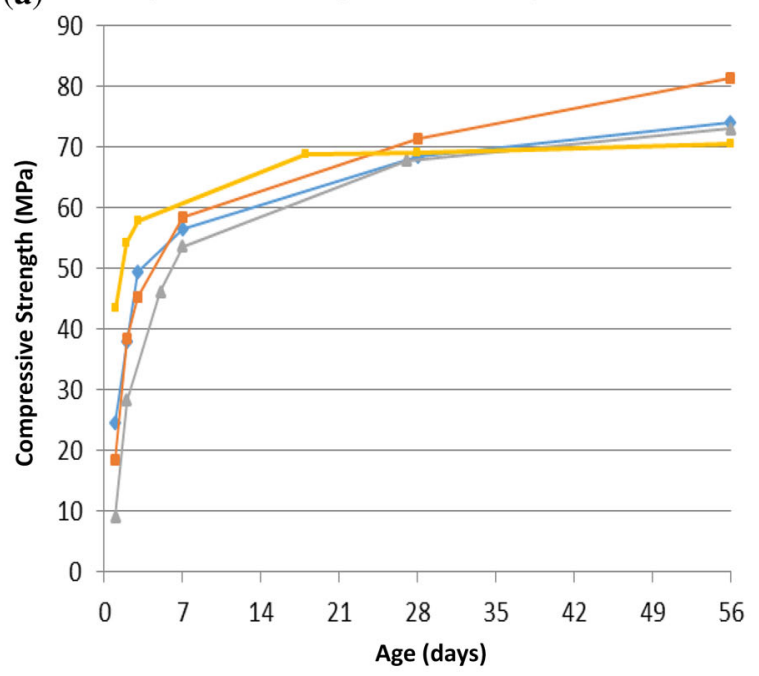

(b) $=-70 \mathrm{OPC} / 30 \mathrm{GGBS} \rightarrow 60 \mathrm{PC} / 40 \mathrm{GGBS}=-50 \mathrm{PC} / 50 \mathrm{GGBS}=-100 \mathrm{PC}$-Control

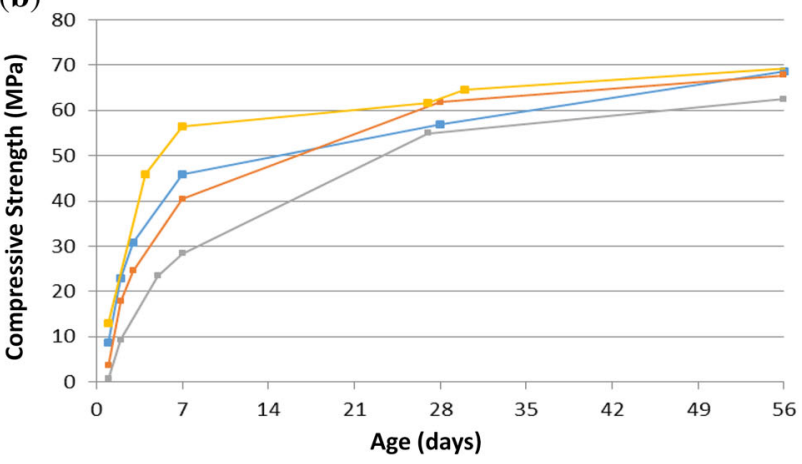

Figure 7. Compressive strength development of GGBS concrete under different curing conditions. (a) Under curing condition $\mathrm{C} 1$, (b) Under curing condition $\mathrm{C} 2$.

were dried at room temperature for $3 \mathrm{~h}$ before testing. The specimens were loaded at a rate of $0.4 \mathrm{~N} / \mathrm{s}$ until failure, following the method described in EN 12390-3 (2009).

\section{Results and discussion}

The strength for various mixes of concrete under two curing conditions $\mathrm{C} 1$ and $\mathrm{C} 2$ are shown in table 5. The compressive strengths of GGBS concrete under water curing C3 are given in table 6. The strength development of blended concrete under $\mathrm{C} 1$ and $\mathrm{C} 2$ conditions is compared with PC for different mixes in figure 7.

\subsection{Strength development of blended concrete with $G G B S$}

The strength development in blended concrete at the early ages decreases with the increase of GGBS content as compared to PC. There is a marked difference in strength gain between the 3 and 7 days' compressive strength; however, this difference is negligible at 28 days. This shows that initially the strength gain of GGBS concrete is slow but it enhances rapidly between 7 and 14 days. The specified strength of GGBS concrete at 28 days is more than PC, which supports its use for structural concrete and other major works. The 56 days' compressive strength is highest for 60PC/40GGBS combination under summer environment, which represents the optimum level of cement replaced by GGBS for the particular batch of GGBS used in this research.

Maximum cement saving has been achieved for mix 50PC/50GGBS, which has reduced the cement consumption by $50 \%$, that is, $229 \mathrm{~kg} / \mathrm{m}^{3}$. The 28 days' compressive strength under summer condition of curing for $50 \mathrm{PC} /$ 50GGBS is almost the same as 100PC with no GGBS. This enables greater opportunity for saving cement and thereby reducing the emission of GHG. The average 56 days' strength of GGBS concrete under summer environment of curing is more than PC for all mixes.

It can be seen that all the concrete mixes cured under regime $\mathrm{C} 1$, except $50 \mathrm{PC} / 50 \mathrm{GGBS}$, have satisfied the requirement of $25 \mathrm{MPa}$, compressive strength after $38 \mathrm{~h}$. Except 50PC/50GGBS, all of the other concrete mixes cured in the $\mathrm{C} 1$ environment had strengths in the range of 18-43 $\mathrm{MPa}$ at the age of 1 day, which is sufficient to be used in fast-track construction. It can be seen from figure 7 that all of the concrete mixes have nearly the same 28-day strength, but there is a greater increase in the compressive strength of 60PC/40GGBS than the other mixes at 56 days.

It is concluded that the concrete containing 30\%, $40 \%$ and $50 \%$ GGBS gains more strength than the PC concrete after the age of 28 days, which is according to the earlier research [34].

At 56 days, the strengths of $70 \mathrm{PC} / 30 \mathrm{GGBS}, 60 \mathrm{PC} /$ 40GGBS and 50PC/50GGBS are 5\%, $15.5 \%$ and $3.5 \%$ higher than the 100PC-control concrete mix, respectively, under $\mathrm{C} 1$ curing environment.

\subsection{Strength development of concrete under various curing conditions}

The strength development of GGBS-blended concrete under two extreme conditions are shown in table 5 and 
figure 8. At lower replacement value of cement by GGBS (70PC/30GGBS), the strength development under winter $\mathrm{C} 2$ is slower than summer condition $\mathrm{C} 1$. Under summer condition C1, GGBS-blended concrete gains almost half of its 56 days' strength at the age of 2 days, where, under $\mathrm{C} 2$, the level is achieved at approximately 4 days. The strength gain after 7 days is, however, at the same pace, and at 56 days, there is no much difference in the compressive strength under the two curing conditions. This difference (i.e., 69 and $74 \mathrm{MPa}, \sim 6 \%$ ). This difference increases to $\sim 15 \%$ for the other two cases of blended concrete. The difference for PC only is negligible.

The strength gain under winter conditions at the early ages before 3 days is $<20 \mathrm{MPa}$ for $60 / 40$ and 50/50 mix. It is concluded that in winter for GGBS concrete up to $50 \%$ special care should be taken regarding the temperature of the curing environment at early ages.

The strength development for $70 \mathrm{PC} / 30 \mathrm{GGBS}, 60 \mathrm{PC} /$ 40GGBS, 50PC/50GGBS and 100PC-Control concrete mixes under different curing regimes are compared in figure 7. In all concrete mixes, the strength development under curing regime $\mathrm{C} 2$ is lower than the strength development under curing regimes $\mathrm{C} 1$ and $\mathrm{C} 3$.

As in curing regime $\mathrm{C} 1$, concrete was cured in sealed plastic bags to minimise the loss of moisture, all the concrete mixes have nearly the same 28-day strength as that of the concrete mixes cured under regime $\mathrm{C} 3$, except the 100PC-Control concrete mix which has gained more strength at the age of 28 and 56 days under regime $\mathrm{C} 3$ than the other curing regimes. From these results, it can be concluded that at the curing temperature of $20^{\circ} \mathrm{C}$ for GGBS concrete mixes there is not much difference in the ultimate strength if it is cured in sealed bags to minimise the loss of moisture or cured under water. For PC concrete mixes, the ultimate strength is higher if it is cured under water than the other curing regimes.

\subsection{Comparison of flexural strength and modulus of elasticity of GGBS-blended concrete under various curing conditions}

For each concrete mix, flexural test was performed after curing in three curing regimes for 28 days. Flexural test results for the different concrete mixes cured under different regimes are given in table 7 . The flexural strength of GGBS concrete and PC concrete cured under the different regimes are compared in figure 9. Concrete cured under $\mathrm{C} 2\left(7^{\circ} \mathrm{C}\right)$ curing regimes have slightly lower flexural strength than the other regimes considered. Concretes cured under the $\mathrm{C} 3$ (curing at $20^{\circ} \mathrm{C}$ under water) regime have higher flexural strength for GGBS and 100PC-Control concrete mixes than those cured under the $\mathrm{C} 1\left(20^{\circ} \mathrm{C}\right)$ environment.
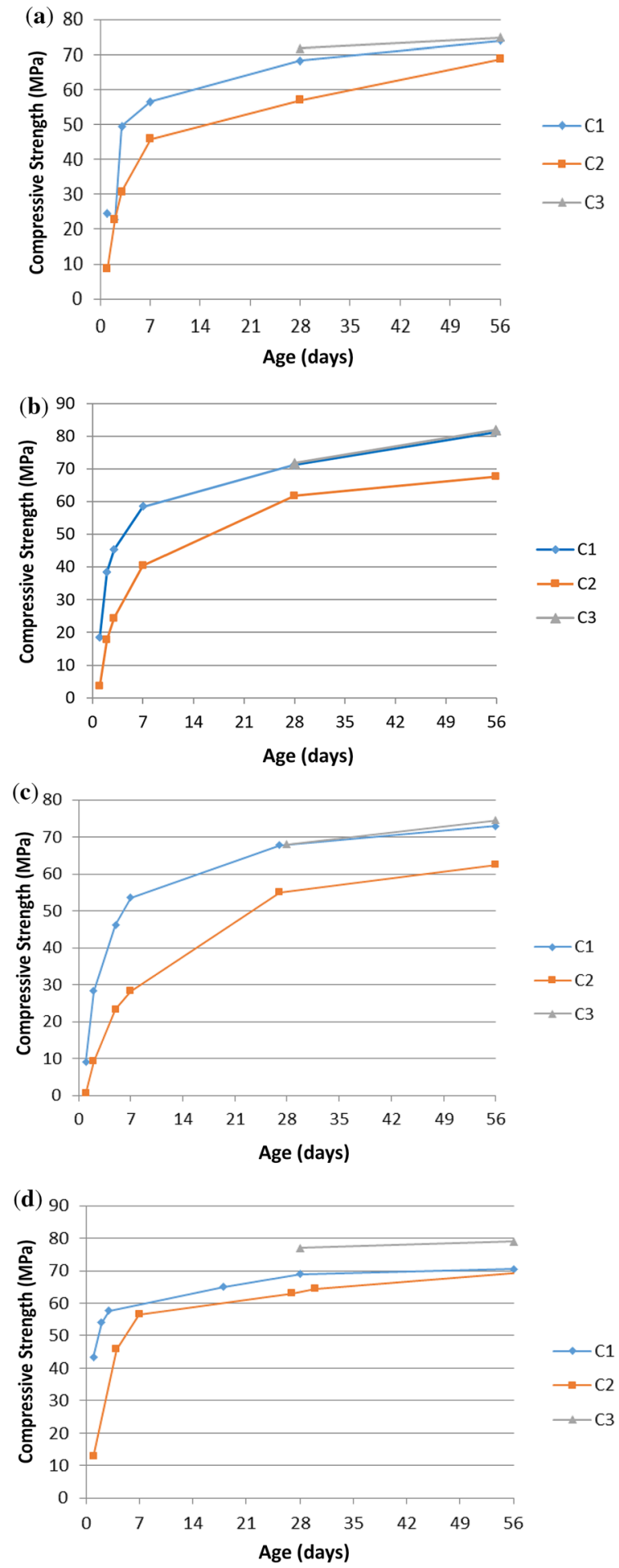

Figure 8. Comparison of strength development for various mixes under different curing conditions. (a) 70PC/30GGBS, (b) 60PC/ 40GGBS, (c) 50PC/50GGBS, and (d) 100 PC control mix.

The 60PC/40GGBS concrete mix gained slightly more flexural strength than the other concrete mixes cured under different curing regimes. The 70PC/30GGBS and 50PC/ 
Table 7. The 28-day flexural strength and modulus of elasticity.

\begin{tabular}{|c|c|c|c|c|c|c|c|c|c|}
\hline \multirow{2}{*}{$\frac{\text { Concrete mix }}{\text { Curing conditions }}$} & \multicolumn{3}{|c|}{ Compressive cylinder strength (MPa) } & \multicolumn{3}{|c|}{ Flexural strength (MPa) } & \multicolumn{3}{|c|}{ Modulus of elasticity (GPa) } \\
\hline & $\mathrm{C} 1$ & $\mathrm{C} 2$ & $\mathrm{C} 3$ & $\mathrm{C} 1$ & $\mathrm{C} 2$ & $\mathrm{C} 3$ & $\mathrm{C} 1$ & $\mathrm{C} 2$ & $\mathrm{C} 3$ \\
\hline 70PC/30GGBS & 56.5 & 49.0 & 58.5 & 6.5 & 6.0 & 7.0 & 40.0 & 38.5 & 40.5 \\
\hline 60PC/40GGBS & 57.0 & 48.0 & 58.0 & 6.5 & 6.0 & 7.0 & 40.5 & 39.0 & 41.0 \\
\hline 50PC/50GGBS & 53.0 & 47.5 & 54.0 & 6.5 & 6.0 & 7.0 & 40.5 & 38.5 & 40.0 \\
\hline 100PC-Control & 56.0 & 55.0 & 57.5 & 6.0 & 6.0 & 7.0 & 39.8 & 38.5 & 39.8 \\
\hline
\end{tabular}

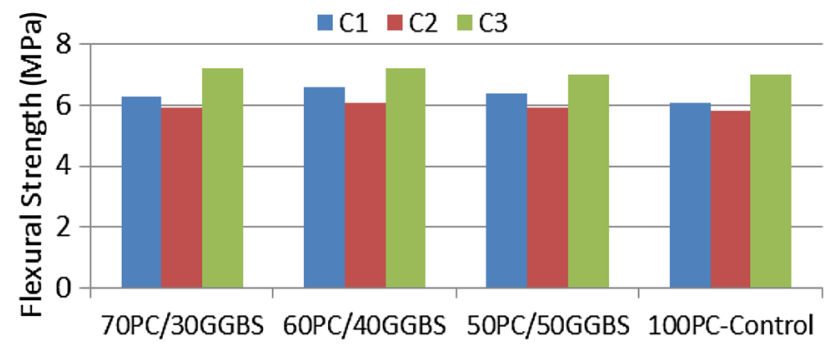

Figure 9. Flexural strength of GGBS concrete at the age of 28 days.

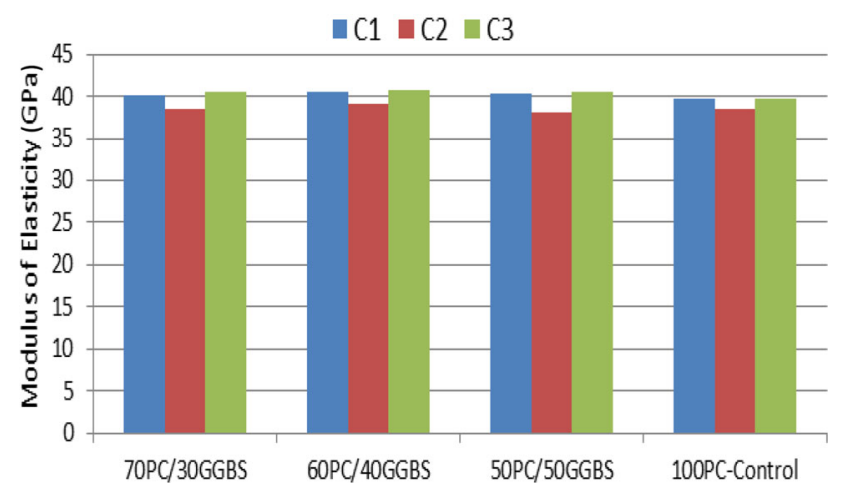

Figure 10. Modulus of elasticity of GGBS concrete at the age of 28 days.

50GGBS concrete mixes have slightly higher flexural strength than the 100PC-Control concrete mix, which was expected according to the literature reviewed.

It is revealed from the test results that the concrete mixes, designed for equal 28 days' strength, the use of GGBS up to $50 \%$, has slightly increased the 28 days' flexural strength in comparison to PC only concrete, which is according to the earlier research due to the better microstructure and packing of concrete [35].

6.3a Modulus of elasticity: From the modulus of elasticity results, it is concluded that concrete samples containing GGBS have higher values of modulus of elasticity than the PC concrete at the summer curing temperatures $\left(20^{\circ} \mathrm{C}\right)$. The value of 28 -day modulus of elasticity of concrete containing 30\%, $40 \%$ and $50 \%$ GGBS are, respectively, $1 \%, 2 \%$ and $1.3 \%$ higher than the PC concrete mix, cured under the summer curing environment.
The winter curing environment has an adverse effect on the 28-day modulus of elasticity values of GGBS and PC concrete, similar to the compressive strength values. It is concluded that proper curing of GGBS concrete under water at $20^{\circ} \mathrm{C}$ or by the prevention of loss of moisture and storing at $20^{\circ} \mathrm{C}$ enhances the modulus of elasticity. Concrete mixes cured under water at $20^{\circ} \mathrm{C}$ have the higher value of modulus of elasticity than the concrete cured in sealed plastic bags at $20^{\circ} \mathrm{C}$. The comparison of modulus of elasticity for GGBS concrete under various curing conditions is given in figure 10 .

\section{Conclusion}

Partial replacement of cement by GGBS up to $50 \%$ has little impact on the compressive strength at 56 days, as the compressive strength achieved has a reasonable value for use in structural works. This can offer greater opportunity for saving of cement and $\mathrm{CO}_{2}$ emissions, thereby making concrete relatively sustainable.

The strength development results show that at low water/ cement ratio (0.35), concrete containing GGBS up to $50 \%$ gains enough high early-age strength to be used in posttensioned concrete and fast-track construction.

The results shows that there are significant reductions in the rate of strength gain of concrete cured under winter curing conditions $\left(7^{\circ} \mathrm{C}\right)$, as compared to those of summer curing and under water $\left(20^{\circ} \mathrm{C}\right)$. In winter conditions, for concrete containing GGBS up to $50 \%$, special care should be taken regarding temperature increase of the curing environment at the early age to gain enough strength. This can be achieved at covering the concrete in sealed conditions. The heating of concrete buildings to increase the temperature for curing is a common practice in cold areas.

From the compressive strength development of GGBS concrete results, it is concluded that concrete containing GGBS up to $50 \%$ has almost the same 28-day compressive strength as PC concrete, when cured under summer temperatures $\left(20^{\circ} \mathrm{C}\right)$ and gains more strength than the $\mathrm{PC}$ concrete at the age of 56 days. Concrete containing $40 \%$ GGBS has the highest compressive strength compared to the other concrete mixes at the age of 56 days and is $15.5 \%$ more than the strength of PC concrete. The strength gain in GGBS concrete is more obvious between the ages of 28 and 56 days. This supported the earlier research to use 56 days' compressive strength of blended concrete. 
Concrete containing GGBS up to $50 \%$ have higher values of flexural strength than the PC concrete when cured under the summer curing environment $\left(20^{\circ} \mathrm{C}\right)$. The 28 -day flexural strength of $30 \%, 40 \%$ and $50 \%$ GGBS concrete mixes are $3.3 \%, 8.2 \%$ and $4.9 \%$ higher, respectively, than the PC concrete mix cured under the summer temperature.

Curing environments have an effect on the flexural strength of GGBS concrete mixes and this is reduced after being cured under winter environments $\left(7^{\circ} \mathrm{C}\right)$ compared to summer temperatures of $20^{\circ} \mathrm{C}$ in sealed plastic bags or under water. GGBS concrete and the PC concrete mixes cured under water at $20^{\circ} \mathrm{C}$ have higher flexural strength than the concrete cured in sealed plastic bags at $20^{\circ} \mathrm{C}$.

\section{References}

[1] Brundtland Commission 1987 Our common future technical report. World Commission on Environment and Development (WCED). Oxford: Oxford University press

[2] Struble L and Godfrey J 2004 How sustainable is concrete. In: Proceedings of the International Workshop on Sustainable Development and Concrete Technology Beijing, China, May 20-21, 2004. Centre for Transportation Research and Education, Iowa State University Ames, Iowa, USA, pp. 201-211

[3] United Kingdom Quality Ash Association 2010 Embodied $\mathrm{CO}_{2}$ of UK cement, additions and cementitious material. Technical data sheet 8.3, MPA; UK Quality Ash Association. Available at http://www.ukqaa.org.uk (Accessed October 4, 2012)

[4] Harrison A J W 2003 TecEco cement concretes-abatement, sequestration and waste utilization in the built environment. TecEco Pty. Ltd., Hobart, Tasmania, Australia. Available at: http://www.tececo.com/files/conference\%20papers/TecEco TechnologyAbatementSequestrationandWasteUtilsation 2901 05.pdf. (Accessed March 12, 2012)

[5] Alaa M R, Hosam El-Din H S and Amir F S 2014 Effect of silica fume and slag on compressive strength and abrasion resistance of HVFA concrete. Int. J. Concr. Struct. Mater. 8(1): 69-81

[6] Ujhelyi J E and Ibrahim A J 1991 Hot weather concreting with hydraulic additives. Cem. Concr. Res. 21(2-3): 345-354

[7] Siddique R and Deepinder K 2012 Properties of concrete containing ground granulated blast furnace slag (GGBS) at elevated temperatures. J. Adv. Res. 3: 45-51

[8] Darren T Y, Limda DA XU, Divsholi B, Sabet Kondraivendhan B and Susanto T 2011 Effect of ultra fine slag replacement on durability and mechanical properties of high strength concrete. 36th Conference on 'Our world in Concrete and Structures', Singapore 10

[9] Malhotra V M and Mehta P K 1996 Pozzolanic and cementitious materials. Overseas, p 191

[10] Swamy R N 1999 Role of slag in the development of durable and sustainable high strength concretes. In: Proceedings of International Symposium on concrete technology for sustainable development in the 21st Century. Hyderabad, pp. 186-121

[11] Rajamane N P, Annie Peter J, Dattatreya J K, Neelamegam $\mathrm{M}$ and Gopalakrishnan S 2003 Improvement in properties of high performance concrete with partial replacement of cement by ground granulated blast furnace slag. IE (I) $J$. 84(8): 42

[12] Bernal S A, Rodríguez E D, Mejía de Gutiérrez R and Provis J L 2015 Performance at high temperature of alkali-activated slag pastes produced with silica fume and rice husk ash based activators. Mater. de Constr. 65(318): 049, doi:10.3989/mc. 2015.03114

[13] Barnett S J, Soutsos M N, Millard S G and Bungey J H 2006 Strength development of mortars containing ground granulated blast-furnace slag: effect of curing temperature and determination of apparent activation energies. Cem. Concr. Res. 36: 434-440

[14] Xian Jun Lu and Jun Q 2010 Alkali activation of granulated blast furnace slag. Adv. Mater. Res. 158(1): 1-11

[15] Wang L, Tian P and Yao Y 2004 Application of ground granulated blast furnace slag in high-performance concrete in China. In: Proceedings of International Conference on Sustainability and Concrete Technology, Beijing, China

[16] Nabil B and Simon F 2005 Use of fly ash and slag in concrete. A Best practice guide. Publication No. MTL 2004-16 (TR-R), Govt of Canada p 46

[17] Saeed A and Shah A 2007 Effects of granulated blast furnace slag on the alkali aggregates reactions of various types of concrete. 32nd Conference on Our World in Concrete \& Structures. August 28-29, Singapore

[18] David N R 2006 Strength and durability of a 70\% ground granulated blast furnace slag concrete mix Organizational Research Report No. RI99-035/RI99-035B, Missouri Department of Transportation USA: $\mathrm{p} 85$

[19] Qureshi M N and Somnath G 2013 Effect of curing conditions on the compressive strength and microstructure of alkali-activated GGBS paste. Int. J. Eng. Sci. Invent. 2(2): 24-31

[20] Islam M M, Islam M S, Mondal B P and Islam M R 2010 Strength behavior of concrete using slag with cement in sea water environment. J. Civil Eng. 38(2): 129-140

[21] SCA 2003 Compressive and flexural strength: slag cement in concrete: Slag Cement Association No 14. Available at: www.slagcement.org (Accessed September 20, 2009)

[22] Oner A and Akyuz S 2007 An experimental study on optimum usage of GGBS for the compressive strength of concrete. Cem. Concr. Compos. 29: 505-514

[23] Chu V T H 2007 What-is-the-advantage-of-using-ggbs-asreplacement-of-cement-in-concrete. A self learning manualmastering different fields of civil engineering works

[24] Clear C A 1995 Formwork striking times for ground granulated blastfurnace slag concrete. Proc Inst. Civil Eng. Struct. Build. Lond. 104(4): 441-448

[25] Higgins D 2006 Sustainable concrete: how can additions contribute. In: Proceedings of the Institute of Concrete Technology Annual Technical Symposium. Institute of Concrete Technology Camberley, UK

[26] Chen J $2005 \mathrm{CO}_{2}$ emissions relief through blended cements. Interdisciplinary Team Research in Civil Engineering Materials, North-western University, Centre for Advanced Cement-Based Materials

[27] Jasen G and Stephon L S 2006 The effective use of groundgranulated blast furnace slag to reduce greenhouse gas emissions. Concrete 40(10): 92-93

[28] Thomas R 2009 West Thames College-making grey green and keeping it beautiful Concrete, July 2009 
[29] Parker J 2012 Building the Shard. Ingenia. Available at: http://www.ingenia.org.uk/ingenia/articles.aspx?index=790, (Accessed 12 September 2012)

[30] Hanson 2010 REGEN The strength behind sustainable concrete. London: Hanson Cement, Heidelberg cement group

[31] British Standard Institute 2011 BS EN 197-1:2011. Composition, specifications and conformity criteria for common cements. British Standard Institute, London

[32] British Standard Institute 2009 BS EN 12620-1:2009. Aggregates for concrete. British Standard Institute, London
[33] British Standards Institution 2009 BS EN 12390-3: 2009. Testing hardened concrete. Part 3: Compressive strength of test specimens. British Standards Institute, London

[34] Khatib J M and Hibbert J J 2005 Selected engineering properties of concrete incorporating slag and metakaolin. Constr. Build. Mater. J. 19: 460-472

[35] Solanki J V and Pitroda J 2013 Flexural strength of beams by partial replacement of cement with fly ash and hypo sludge in concrete. Int. J. Eng. Sci. Innov. Technol. 2 (1): 173-179 